\title{
TNF $\alpha$ regulates the expression of the CSE gene in HUVEC
}

\author{
MAOXIAN WANG \\ Department of Biological Sciences, Hanshan Normal University, Chaozhou, Guangdong 521041, P.R. China
}

Received November 11, 2020; Accepted March 11, 2021

DOI: $10.3892 / \mathrm{etm} .2021 .10667$

\begin{abstract}
The hydrogen sulfide $\left(\mathrm{H}_{2} \mathrm{~S}\right) /$ cystathionine $\gamma$-lyase (CSE) signaling pathway is involved in several inflammatory conditions, where tumor necrosis factor- $\alpha(\mathrm{TNF} \alpha)$ is one of the inflammatory cytokines activated during sepsis. Therefore, the present study investigated the role of the $\mathrm{NF}-\kappa \mathrm{B}$ transcription factor binding site in the transcriptional regulation of the CSE gene in 293T cells following treatment with TNF $\alpha$ using luciferase assays, as well as using western blotting and reverse transcription-quantitative PCR to examine the effect of TNF $\alpha$ on CSE expression in HUVECs. After transfected $293 \mathrm{~T}$ cells were incubated with various concentrations of $\mathrm{TNF} \alpha$ for 1,3 , and $6 \mathrm{~h}$, the wild-type promoter of the CSE gene increased significantly at $1 \mathrm{~h}$ compared to $0 \mathrm{~h}$. By contrast, after the transfected $293 \mathrm{~T}$ cells were incubated with various concentrations of TNFa for $1 \mathrm{~h}$, the mutant-type promoter activity of the CSE gene decreased significantly compared to the wild-type. These results revealed that the DNA sequence GGGACATTCC on the CSE gene promoter was directly associated with the transcriptional regulation of the CSE gene in Human cells (293T cells) that's were treated with TNF $\alpha$. This suggests that TNF $\alpha$ affects CSE gene expression, such that vascular endothelial cells respond to TNF $\alpha$ in the blood by regulating CSE expression. The regulatory mechanisms associated with the effects of TNF $\alpha$ on the transcriptional regulation of the CSE gene in HUVECs and the NF- $\kappa$ B pathway warrant further investigation.
\end{abstract}

\section{Introduction}

Cystathionine $\gamma$-lyase (CSE) is one of the three enzymes in the transsulfuration pathway that is responsible for producing endogenous hydrogen sulfide $\left(\mathrm{H}_{2} \mathrm{~S}\right)$ (1). NaHS (an $\mathrm{H}_{2} \mathrm{~S}$ donor) activates p38 and Akt, increasing the expression of angiogenic factors and the proliferation of HUVECs (2).

Correspondence to: Professor Maoxian Wang, Department of Biological Sciences, Hanshan Normal University, Qiaodong, Xiangqiao, Chaozhou, Guangdong 521041, P.R. China

E-mail: wangmx@hstc.edu.cn; wmaoxcn@gmail.com

Key words: cystathionine $\gamma$-lyase, endothelial cells, hydrogen sulfide, tumor necrosis factor- $\alpha$
$\mathrm{H}_{2} \mathrm{~S}$ is a gaseous endogenous mediator that serves a potential role in modulating gastric inflammatory responses (3). In particular, S-propargyl-cysteine is a $\mathrm{H}_{2} \mathrm{~S}$ donor that can enhance human umbilical vein endothelial cell (HUVEC) cell proliferation, adhesion, migration and tube formation (4). By contrast, exogenous thiosulfates, which act in a slow manner to modulate sulfide metabolites, have been documented to inhibit vascular endothelial growth factor (VEGF)-dependent endothelial cell proliferation in a manner that is associated with reductions in CSE protein levels (5). $\mathrm{H}_{2} \mathrm{~S}$ has been shown to inhibit the activation of $\mathrm{NF}-\kappa \mathrm{B}$ and the production of tumor necrosis factor- $\alpha(\mathrm{TNF} \alpha)$ in cultured uterine smooth muscle cells (6). Following CSE knockdown, treatment with L-aspartate- $\beta$-hydroxamate, an aspartate aminotransferase (AAT) inhibitor that blocks the generation of endogenous sulfur dioxide $\left(\mathrm{SO}_{2}\right)$ /AAT induced, was found to aggravate the activation of the $\mathrm{NF}-\kappa \mathrm{B}$ pathway in endothelial cells and its downstream inflammatory factors, including $\mathrm{TNF} \alpha$ and interleukin (IL)-6 (7). $\mathrm{H}_{2} \mathrm{~S}$ exerts both pro-and antinociceptive effects through inflammation (8). In addition, a previous study observed an increase in inflammatory cytokine (IL-6 and $\mathrm{TNF} \alpha$ ) expression in the heart, and acute kidney injury (AKI) can downregulate CSE-mediated $\mathrm{H}_{2} \mathrm{~S}$ production, reduce glutathione levels and increase oxidative stress in the heart (9).

$\mathrm{NF}-\kappa \mathrm{B}$ is a heterodimer that is involved in a variety of signaling pathways (10). As such, $N F-\kappa B$ can regulate inflammatory responses by inducing the expression of a number of genes, such as IL-6 and intercellular adhesion molecule-1 (11), whilst NaHS suppresses intracellular adhesion molecule-1 expression in TNF $\alpha$-treated HUVECs (12). TNF $\alpha$ is the multifunctional cytokine that is secreted primarily by macrophages, natural killer (NK) cells and lymphocytes (13). $\mathrm{H}_{2} \mathrm{~S}$ can prevent an endothelial monolayer activation triggered by TNF $\alpha$. The mechanism of this protective effect is mainly mediated by downmodulation of ADAM17-dependent TNF-converting enzyme activity with consequent inhibition of soluble TNF-a shedding and its relevant MCP-1 release in the medium (14). CSE knockdown has been shown to protect primary hepatocytes from D-galactosamine/TNF $\alpha$-induced cell death without affecting LPS-induced TNF $\alpha$ production by primary peritoneal macrophages (15). LPS induces significant increases in the plasma levels of multiple cytokines (TNF $\alpha$, IL-1 $\beta$, IL-6, IL-10, IL-12 and interferon $\gamma$ ), but TNFa, IL-10 and IL-12 levels tended to be lower in male WT mice (C57/BL6) compared with heterozygous cystathionine $\beta$-synthase (CBS) mice and CSE-knockout mice, which express lower $\mathrm{H}_{2} \mathrm{~S}$-producing enzymes CBS, CSE and 
3-mercaptopyruvate sulfurtransferase (16). The findings indicate that CSE ameliorates the outcome of LPS-induced endotoxemia in vivo (16). By contrast, exogenous $\mathrm{H}_{2} \mathrm{~S}$ can attenuate angiotensin II-induced inflammation and cytotoxicity by inhibiting the endothelin $1 / \mathrm{NF}-\kappa \mathrm{B}$ signaling pathway in HUVECs (17). CSE-generated $\mathrm{H}_{2} \mathrm{~S}$ has also been shown to promote prostate cancer progression and metastasis through the IL-1 $\beta / N F-\kappa B$ signaling pathway (18). In addition, $\mathrm{H}_{2} \mathrm{~S}$ can regulate lipopolysaccharide (LPS)-induced inflammation and apoptosis of the mammary alveolar epithelial cell lines, MAC-T by activating the PI3K/Akt/NF- $\kappa \mathrm{B}$ signaling pathway (19).

The inflammatory cytokine TNF $\alpha$ serves a pivotal role in the disruption of macrovascular and microvascular circulation both in vivo and in vitro (20). Although the $\mathrm{H}_{2} \mathrm{~S} / \mathrm{CSE}$ signaling pathway is involved in inflammation (19,21-23), mechanism underlying regulation of the CSE gene in HUVECs following treatment with TNF $\alpha$ remains poorly understood. Therefore, the aim of the present study was to investigate the role of the $\mathrm{NF}-\kappa \mathrm{B}$ transcription factor binding site on the transcription of the CSE gene in HUVECs that were treated with TNFa.

\section{Materials and methods}

Construction of the luciferase reporter under the control of human CSE promoter. HUVECs were obtained from the School of Pharmacy of Fudan University. The cultured cells were maintained in DMEM (Thermo Fisher Scientific, Inc.) supplemented with 10\% FBS (Thermo Fisher Scientific, Inc.), $100 \mathrm{U} / \mathrm{ml}$ penicillin, and $0.1 \mathrm{mg} / \mathrm{ml}$ streptomycin in a humidified atmosphere composed of $95 \%$ air and $5 \% \mathrm{CO}_{2}$ at $37^{\circ} \mathrm{C}$. HUVECs were cultured to a confluence of $80-90 \%$ and digested with trypsin at 5,000 g/5 min with RT. The cells were collected into a $1.5 \mathrm{ml}$ centrifuge tube. Subsequently, genomic DNA was extracted from the HUVECs using a blood genomic DNA extraction kit (Beijing Transgen Biotech Co., Ltd.). For identification, $1 \%$ agarose gel electrophoresis was used. The sequence of the human CSE gene promoter was searched on the GenBank database, based on which the upstream and downstream primers were designed. The target fragment DNA length was $710 \mathrm{bp}(-696 \pm 16 \mathrm{nt})$. According to the GenBank database of the human CSE (accession no. NG_008041.1) gene promoter sequences and the Primer-BLAST online application (https://www.ncbi.nlm.nih.gov/tools/primer-blast/), a 710-bp DNA transcription start site of human CSE gene was amplified by PCR using the HUVEC genomic DNA as the template (forward, 5'-CGGGGTACCCATTAGGGGGAGTTTCTC TCTGT-3' and reverse, 5'-CCGCTCGAGCTGCAGTCTCAC GATCACAGT-3'; Promega Corporation). The PrimeSTAR HS DNA Polymerase PCR kit (cat. no. R010A) was purchased from Takara Bio, Inc. The thermocycling conditions were as follows: Initial denaturation at $94^{\circ} \mathrm{C}$ for $3 \mathrm{~min}$; followed by 30 cycles at $95^{\circ} \mathrm{C}$ for $30 \mathrm{sec}, 60^{\circ} \mathrm{C}$ for $45 \mathrm{sec}$ and $72^{\circ} \mathrm{C}$ for $90 \mathrm{sec}$; and a final step at $72^{\circ} \mathrm{C}$ for $10 \mathrm{~min}$. The PCR product was digested with the restriction enzymes KpnI and XhoI (Takara Biotechnology Co., Ltd.) and cloned into the pGL4.12 vector (Promega Corporation) that containing a firefly luciferase gene driven by the inserted promoter (pGL4.12). The resultant construct was designated as pGL4.12-HuCSE710. The inserted DNA fragment was confirmed by Sanger sequencing by Sangon Biotech Co., Ltd. The reporter with the mutant CSE promoter was the same as that aforementioned, except that an alternative forward primer (5'-CGGGGTACCCATTAGGAT CTGTTTCTCTCTGT-3') was used during PCR amplification. Both the Wild-type promoter and the Mutant promoter were transformed into Trans $5 \alpha$ chemically competent cells (A strain of Escherichia coli (E. coli); TransGen Biotech Co., Ltd.), cultured overnight at $37^{\circ} \mathrm{C}$ before a single bacterial colony was selected, followed by culture overnight in a shaking bed at $37^{\circ} \mathrm{C}$ for amplification. Plasmids were extracted using the EasyPure Plasmid MiniPrep kit (cat. no. EM101-01; TransGen Biotech Co., Ltd.), which was analyzed by restriction enzyme digestion. The fragment size was identified and sequenced by Sanger sequencing by Sangon Biotech Co., Ltd. The sequencing results were compared with the published sequences on the GenBank database for analysis.

Cell culture and treatments. 293T cell lines (cat. no. GNHu17) were purchased from The Cell Bank of Type Culture Collection of the Chinese Academy of Sciences. Cell culture reagents were purchased from Thermo Fisher Scientific, Inc. The 293T cells and HUVECs were cultured in a 5\% $\mathrm{CO}_{2}$ /balance air incubator at $37^{\circ} \mathrm{C}$ in DMEM supplemented with $10 \%$ heat-inactivated FBS and with the addition of $100 \mathrm{U} / \mathrm{ml}$; penicillin $\mathrm{G}, 100 \mu \mathrm{g} / \mathrm{ml}$ streptomycin and $6.5 \mathrm{mM}$ L-glutamine. According to the different cell lines, the transfected $293 \mathrm{~T}$ cells and HUVECs were cultured at a density of $0.5-1 \times 10^{6}$ cells in $35-\mathrm{mm}$ dishes (Corning, Inc.) prior to treatment. For treatment with TNF $\alpha$ (Recombinant Human 4-1BB Receptor, $5 \mu \mathrm{g}$; Beyotime Institute of Biotechnology), all tested cells were incubated with $\mathrm{TNF} \alpha(10,30$ and $50 \mathrm{ng} / \mathrm{ml}$ ) for 1,3 and $6 \mathrm{~h}$ at $37^{\circ} \mathrm{C}$. The controls received the same volume of saline as the TNF $\alpha$-treated cells. Following incubation and the removal of the cell medium, luciferase assay, reverse transcription-quantitative (RT-qPCR) and western blot analysis were performed.

Luciferase assay. For transfection, the 293T cells were grown to $70-80 \%$ confluency. Subsequently, $5 \mu \mathrm{g}$ pGL4.12-HuCSE710 or pGL4.12-HuCSE710 m (the mutant promoter) together with $0.028 \mu \mathrm{g}$ the pRL-CMV control vector were transfected into the cells per $35-\mathrm{mm}$ dishes using $\mathrm{Xfect}^{\mathrm{TM}}$ transfection reagent (Takara Bio, Inc.) according to the manufacturer's protocols. After $12 \mathrm{~h}$, the transfected cells were sub-cultured in several $35-\mathrm{mm}$ dishes at a proportion of 1:3 for $24 \mathrm{~h}$. Following treatment with TNF $\alpha$ for 1,3 , and $6 \mathrm{~h}$ after $36 \mathrm{~h}$ of transfection, both Firefly luciferase and Renilla luciferase activities were assayed using the TransDetect Double-Luciferase Reporter Assay kit (Beijing Transgen Biotech Co., Ltd.) according to the manufacturer's protocol using the Multimode Microplate Reader (Berthold Technologies GmbH \& Co., K.G.). Firefly luciferase activity was normalized against Renilla luciferase activity.

Isolation of RNA and RT-qPCR. According to the manufacturer's protocol, total RNA of HUVECs was isolated using the TransZol Up reagent (Beijing Transgen Biotech Co., Ltd.). Reaction Mix and TransScript ${ }^{\circledR}$ RT/RI Enzyme mix (Transgen Biotech Co., Ltd.) was used for reverse transcription. The temperature protocol for reverse transcription was as follows: Incubation at $42^{\circ} \mathrm{C}$ for $30 \mathrm{~min}$ and inactivation at $85^{\circ} \mathrm{C}$ for 
Table I. Primers used for reverse transcription-quantitative PCR.

\begin{tabular}{|c|c|c|c|c|}
\hline Gene & GenBank Accession number & Primer sequence & Exon & Amplicon size \\
\hline \multirow[t]{2}{*}{$C S E$} & NM_001902.5 & F:5'-GGCTCTACCTGCGTGCTTTA-3' & 1 & $118 \mathrm{bp}$ \\
\hline & & R:5'-CGCGAAAGAAGAAGAGAGGA-3' & 1 & \\
\hline \multirow[t]{2}{*}{$A C T B$} & NM_001101.3 & F:5'-CTCTTCCAGCCTTCCTTCCT-3' & 2 & $109 \mathrm{bp}$ \\
\hline & & R:5'-TGTTGGCGTACAGGTCTTTG-3' & 2 & \\
\hline
\end{tabular}

CSE, cystathionine $\gamma$-lyase; ACTB, $\beta$-actin.

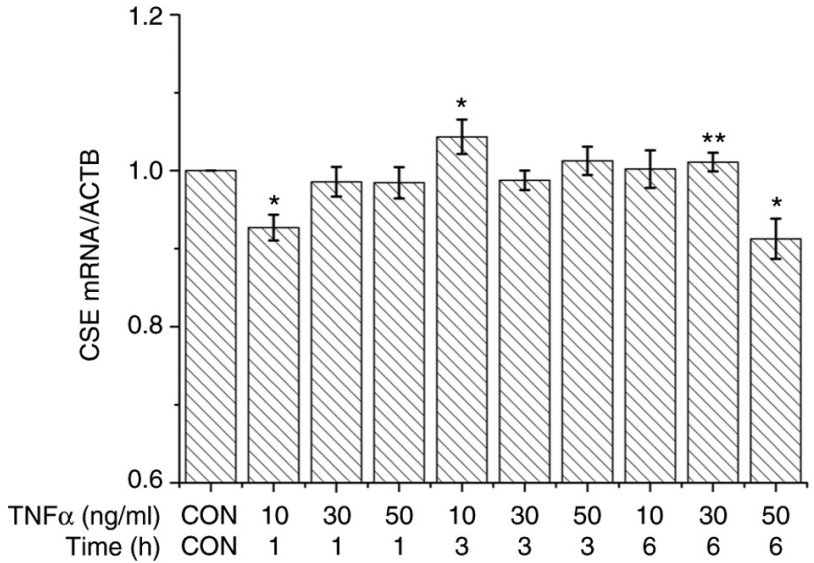

Figure 1. Effects of TNF $\alpha$ on the CSE gene transcription in HUVECs at the mRNA level. Following treatment with $\mathrm{TNF} \alpha(10,30$ and $50 \mathrm{ng} / \mathrm{ml})$ for 1,3 and $6 \mathrm{~h}, \mathrm{mRNA}$ expression levels of CSE in HUVECs were examined using reverse transcription-quantitative PCR. CSE mRNA levels in HUVECs decreased with $10 \mathrm{ng} / \mathrm{ml} \mathrm{TNF} \alpha$ for $1 \mathrm{~h}$ compared to all other except at $50 \mathrm{ng} / \mathrm{ml}$ for $6 \mathrm{~h}$. Moreover, the CSE mRNA levels in HUVECs increased following treatment with $\mathrm{TNF} \alpha$ at $10 \mathrm{ng} / \mathrm{ml}$ for $3 \mathrm{~h}$. Compared with those in the control, CSE mRNA levels in HUVECs increased with TNF $\alpha$ at $10 \mathrm{ng} / \mathrm{ml}$ for $3 \mathrm{~h}$, did not change significantly or declined in other cases ( $\mathrm{P}<0.05$ and ${ }^{* *} \mathrm{P}<0.01$ vs. CON). CSE, cystathionine $\gamma$-lyase; HUVECs, human umbilical vein endothelial cells; TNF $\alpha$, tumor necrosis factor $\alpha$.

5 sec. TransStart ${ }^{\circledR}$ Green qPCR SuperMix Real-Time PCR kit (Beijing Transgen Biotech Co., Ltd.) was used for qPCR. The following thermocycling conditions were used: Preincubation at $94^{\circ} \mathrm{C}$ for $30 \mathrm{sec}$, followed by a 2-step amplification of $94^{\circ} \mathrm{C}$ for $5 \mathrm{sec}$ and $60^{\circ} \mathrm{C}$ for $30 \mathrm{sec}$. An oligo-dT primer (Beijing Transgen Biotech Co., Ltd.) was used for mRNA reverse transcription. The sequences of the primers used for qPCR are summarized in Table I. To design the primer pairs, CSE Forward Primer/CSE Reversed Primer (Table I) was used to determine the relative expression of CSE. By verifying that both $A C T B$ ( $\beta$-actin gene) and CSE mRNA primers had similar amplifying efficiencies, the comparative $2^{-\Delta \Delta \mathrm{Cq}}$ method was used for performing relative quantification analysis of the mRNA levels (24). Roche LightCycler ${ }^{\circledR} 96$ System (Roche Molecular Diagnostics) was used for cDNA amplification and detection.

Western blot analysis. Western blot analysis was performed according to a previously described method (25). For total protein extraction, $0.5 \times 10^{6}$ HUVECs were incubated in $120 \mu \mathrm{l}$ mild RIPA lysis buffer (Beijing Transgen Biotech Co., Ltd.) supplemented with $1 \mathrm{mM}$ PMSF proteinase, $0.25 \mathrm{U} / \mu \mathrm{l}$

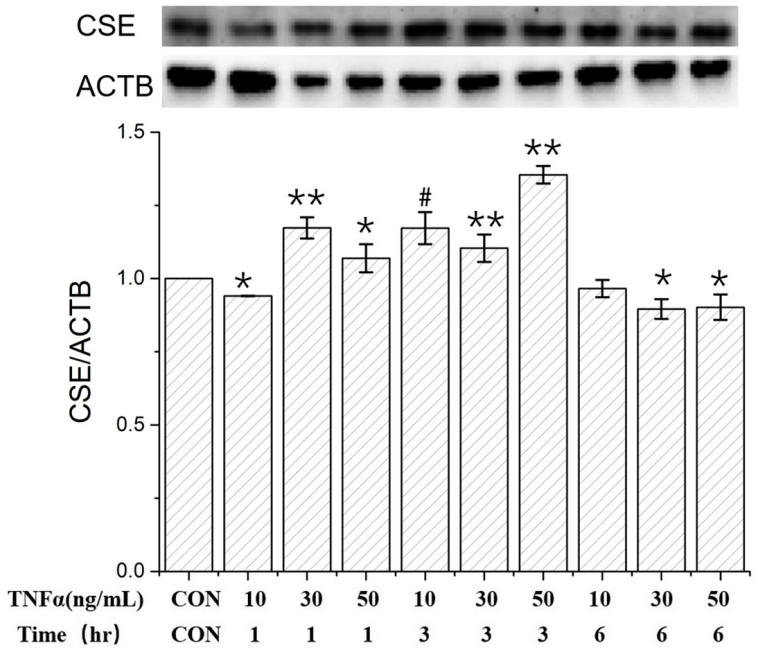

Figure 2. Effects of TNF $\alpha$ on the CSE expression in HUVECs at the protein level. Following treatment with TNF $\alpha(10 \mathrm{ng} / \mathrm{ml})$ for $1 \mathrm{~h}, \mathrm{CSE}$ protein expression significantly decreased compared with that in the control. Following treatment with TNF $\alpha(10,30$ and $50 \mathrm{ng} / \mathrm{ml})$ for 1,3 and $6 \mathrm{~h}$, CSE protein expression in HUVECs increased at the concentration of $10 \mathrm{ng} / \mathrm{ml}$ with $3 \mathrm{~h}$ of treatment compared with $10 \mathrm{ng} / \mathrm{ml}$ after $1 \mathrm{~h}$, whilst the CSE protein level in the HUVECs were increased at the concentration of $50 \mathrm{ng} / \mathrm{ml}$ for $3 \mathrm{~h}$ treatment compared with $50 \mathrm{ng} / \mathrm{ml}$ after $6 \mathrm{~h}$. Compared to the control, CSE protein expression in the HUVECs markedly increased with TNF $\alpha$ at $30 \mathrm{ng} / \mathrm{ml}$ for $1 \mathrm{~h}$ and $50 \mathrm{ng} / \mathrm{ml}$ for $3 \mathrm{~h}$ but declined slightly in other cases $\left({ }^{*} \mathrm{P}<0.05\right.$ and ${ }^{* * *} \mathrm{P}<0.01$ vs. CON; ${ }^{\#} \mathrm{P}<0.05,10 \mathrm{ng} / \mathrm{ml}$ for $3 \mathrm{~h}$ vs. $10 \mathrm{ng} / \mathrm{ml}$ for $\left.1 \mathrm{~h}\right)$. HUVECs, human umbilical vein endothelial cells; TNF $\alpha$, tumor necrosis factor $\alpha$; CSE, cystathionine $\gamma$-lyase.

Benzonase and inhibitor cocktail (Takara Bio, Inc.). The level of protein was determined using the bicinchoninic acid assay method. For $10 \%$ SDS-PAGE, the protein samples $(30 \mu \mathrm{g})$ were mixed with loading buffer and boiled at $98^{\circ} \mathrm{C}$ for $10 \mathrm{~min}$. The separated proteins were transferred onto a $0.45 \mu \mathrm{m}$ PVDF membrane (EMD Millipore). The membrane was incubated at $4^{\circ} \mathrm{C}$ with anti-CSE (cat. no. D199513, Sangon Biotech Co., Ltd.) mouse monoclonal antibodies (1:1,000 dilution) or anti-ACTB (cat. no. D191047, Sangon Biotech Co., Ltd.) mouse monoclonal antibodies (1:2,000 dilution) for $12 \mathrm{~h}$. After another wash, the membrane was incubated with HRP-conjugated goat anti-mouse antibodies (1:5,000 dilution; cat. no. D110087; Sangon Biotech Co., Ltd.) for 2 h, The results were scanned for the detection of CSE and ACTB with BeyoECL Plus (cat. no. P0018S; Beyotime Institute of Biotechnology) and quantified using the AlphaView System (ProteinSimple) sensitive chemiluminescent imaging system 
A

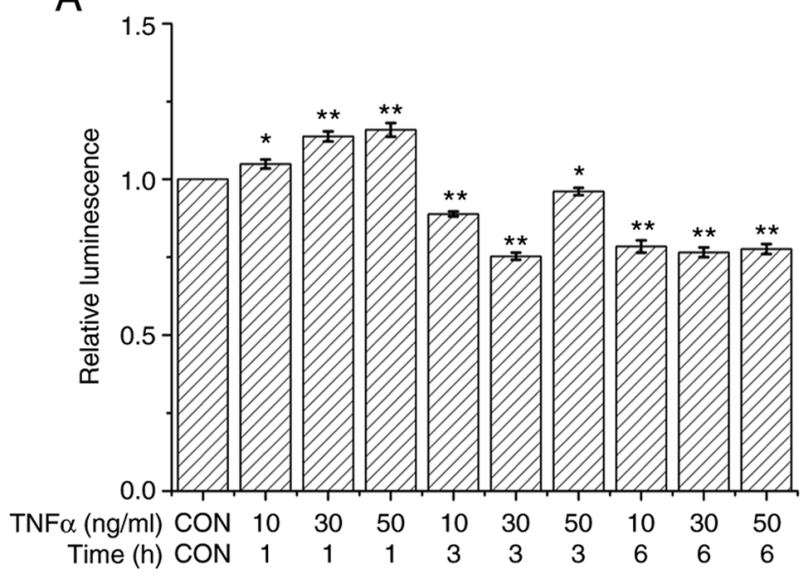

B

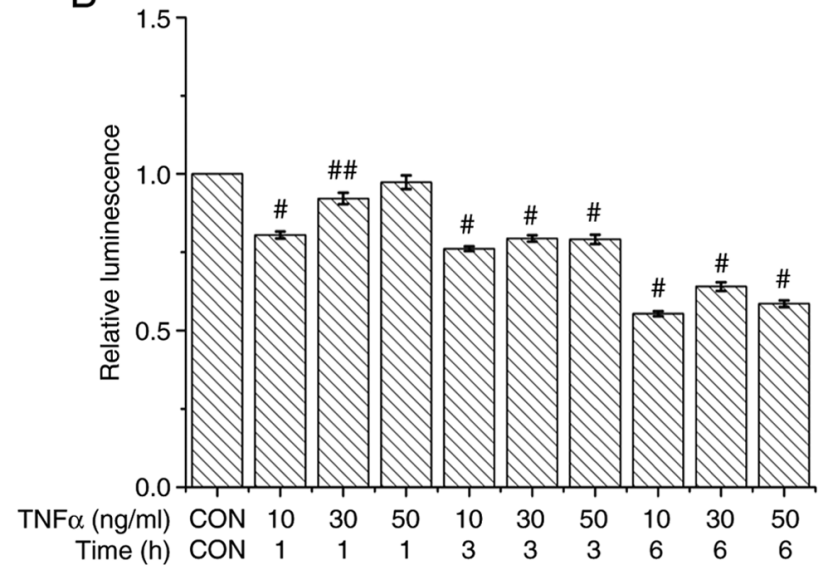

Figure 3. Effects of TNF $\alpha$ on the wild-type or mutant-type promoter luciferase activity of the CSE gene in transfected 293T cells treated with TNF $\alpha$ (10, 30 and $50 \mathrm{ng} / \mathrm{ml}$ ) for 1,3 and $6 \mathrm{~h}$. (A) Wild-type promoter activity of the CSE gene. ${ }^{*} \mathrm{P}<0.05$ vs. CON and ${ }^{* *} \mathrm{P}<0.01$ vs. CON (B) Mutant-type promoter activity of the CSE gene. ${ }^{\#} \mathrm{P}<0.01$ vs. CON and ${ }^{\# \#} \mathrm{P}<0.01$ vs. CON. CSE, cystathionine $\gamma$-lyase; HUVECs, human umbilical vein endothelial cells; TNF $\alpha$, tumor necrosis factor $\alpha$.

with a separate instrument software (FluorChem HD2; v3.4.0; ProteinSimple).

Statistical analysis. All data are expressed as the means \pm SEM from $\geq$ four experiments. Shapiro-Wilk test is used to confirm the normality of the data distribution. Multiple group comparisons were performed using one-way ANOVA followed by Tukey's post hoc test. $\mathrm{P}<0.05$ was considered to indicate a statistically significant difference.

\section{Results}

Effects of TNF $\alpha$ treatment on the CSE mRNA level. To analyze the effects of TNF $\alpha$ on the transcription of the CSE gene, the expression level of CSE mRNA in HUVECs was examined. As shown in Fig. 1, following treatment with TNF $\alpha$ (10, 30 and $50 \mathrm{ng} / \mathrm{ml}$ ) for 1,3 and $6 \mathrm{~h}$, the CSE mRNA levels in HUVECs decreased with $10 \mathrm{ng} / \mathrm{ml} \mathrm{TNF} \alpha$ for $1 \mathrm{~h}$ compared to all other groups except $50 \mathrm{ng} / \mathrm{ml}$ for $6 \mathrm{~h}$. In addition, CSE mRNA levels in HUVECs increased following treatment with TNF $\alpha$ at $10 \mathrm{ng} / \mathrm{ml}$ for $3 \mathrm{~h}$ compared to all other groups. However, CSE mRNA levels of cells treated with higher concentrations of $\mathrm{TNF} \alpha(50 \mathrm{ng} / \mathrm{ml})$ were reduced at $3 \mathrm{~h}$ compared with that at $6 \mathrm{~h}$, where it probably exerted toxic effects on the cells. At $3 \mathrm{~h}$, a ' $U$ ' curve in CSE mRNA expression was observed in the cells treated with ascending concentrations of TNFa. At $6 \mathrm{~h}$, an inverted ' $\mathrm{U}$ ' curve was observed in the expression of CSE mRNA in the cells treated with ascending concentrations of TNF $\alpha$. This result indicated that HUVECs treated with various concentrations of $\mathrm{TNF} \alpha$ differed significantly among the different treatment times.

Effects of TNF $\alpha$ on the CSE protein level. The effect of TNF $\alpha$ on CSE protein expression in HUVECs was next investigated. As shown in Fig. 2, following treatment with $\mathrm{TNF} \alpha(10 \mathrm{ng} / \mathrm{ml})$ for $1 \mathrm{~h}, \mathrm{CSE}$ protein expression decreased significantly compared with that in the control group. Following treatment with $\mathrm{TNF} \alpha(10,30$ and $50 \mathrm{ng} / \mathrm{ml})$ for 1 , 3 and $6 \mathrm{~h}$, the CSE protein level in the HUVECs increased, particularly at the concentration of $10 \mathrm{ng} / \mathrm{ml}$ for $3 \mathrm{~h}$ of treatment compared with that for $1 \mathrm{~h}$. Compared with that in the control, CSE protein expression in the HUVECs increased with $\mathrm{TNF} \alpha$ at $30 \mathrm{ng} / \mathrm{ml}$ for $1 \mathrm{~h}$ and $50 \mathrm{ng} / \mathrm{ml}$ for $3 \mathrm{~h}$ but declined slightly in other conditions compared to all other groups except $10 \mathrm{ng} / \mathrm{ml}$ for $3 \mathrm{~h}$. These results suggested that the same concentration of TNF $\alpha$ exerted differential effects on the CSE protein level in a manner that was dependent on the treatment duration. Although $\mathrm{TNF} \alpha$-induced upregulation of CSE expression within $3 \mathrm{~h}$ at $50 \mathrm{ng} / \mathrm{ml} \mathrm{TNF} \alpha$ was evident compared to all other groups, TNF $\alpha$ can affect CSE expression in a concentration and duration-dependent manner.

Effect of TNF $\alpha$ on the wild-type or mutant promoter activity of the CSE gene. The effects of TNFa on the transactivation activities of the promoter of the CSE gene were subsequently analyzed by transient transfection experiments. By bioinformatics analysis, a potential $\mathrm{NF}-\kappa \mathrm{B}$ binding site was identified on the human CSE gene promoter with the DNA sequence of 5'-GGGACATTCC-3'. The reporter luciferase expression vector was constructed, which was either controlled either by the wild-type (Fig. 3A) or mutant (Fig. 3B) promoter region of the CSE gene, as shown. As shown in Fig. 3A, following treatment with $\mathrm{TNF} \alpha(10,30$ and $50 \mathrm{ng} / \mathrm{ml})$ for 1,3 and $6 \mathrm{~h}$, the wild-type promoter activity of the CSE gene in transfected 293T cells increased with the increment in the concentration of $\mathrm{TNF} \alpha$ at $1 \mathrm{~h}$ compared to all other group.

As shown in Fig. 3B, the CSE gene mutant promoter activity decreased with the concentrations of TNF $\alpha$ at $1 \mathrm{~h}$ compared to TNF $\alpha$ (30 and $50 \mathrm{ng} / \mathrm{ml}$ ) for 1,3 and $6 \mathrm{~h}$. These results revealed that $\mathrm{TNF} \alpha$ regulated CSE gene transcription via the $\mathrm{NF}-\kappa \mathrm{B}$ binding site on the CSE gene promoter in HUVECs. Just as CSE mRNA expression was different following treatment with different concentrations of $\mathrm{TNF} \alpha$, the activity of CSE promoter was also similar at varying concentrations of TNF $\alpha$. These results suggest that the level of $\mathrm{TNF} \alpha$ at different treatment times affected the expression of CSE. 


\section{Discussion}

The $\mathrm{H}_{2} \mathrm{~S}$ /CSE signaling pathway is involved in various inflammatory conditions, whereas $\mathrm{TNF} \alpha$ is one of the inflammatory cytokines that is activated during sepsis (26-29). The concentration of $\mathrm{H}_{2} \mathrm{~S}$ is enhanced when abdominal sepsis or endotoxemia occurs, and administration of $\mathrm{H}_{2} \mathrm{~S}$ leads to exacerbation of these conditions, mainly because of its pro-inflammatory effect $(30,31)$. It has also been reported that the concentration of $\mathrm{H}_{2} \mathrm{~S}$ rose in response to the presence of pancreatitis, which is ascribed to its pro-inflammatory effect (32) NaHS treatment also exerts anti-inflammatory effects through the inhibition of nitric oxide and TNFa production in MC3T3-E1 osteoblastic cells, suggesting an anti-inflammatory effect of $\mathrm{H}_{2} \mathrm{~S}$ (33). The anti-inflammatory effect of $\mathrm{H}_{2} \mathrm{~S}$ has been previously reported, particularly on TNF production, in addition to the molecular mechanisms involving NF- $\kappa B$ inhibition and the reduced expression of IL-6, TNF and IL-1 $\beta$ by $\mathrm{H}_{2} \mathrm{~S}$ (34). For example, $\mathrm{H}_{2} \mathrm{~S}$ production facilitates the pathogenesis of severe acute pancreatitis (35). Additionally, NaHS treatment has been shown to improve wound healing in ob/ob mice (hyperphagic, obese, hyperinsulinemic and hyperglycemic mice), which is associated with the decreased production of TNF $\alpha$ and IL-6 (36). The inflammatory role of $\mathrm{H}_{2} \mathrm{~S}$ remains controversial due to findings that it exerts both proinflammatory and anti-inflammatory effects (37).

TNF- $\alpha$ induces the gene expression of various inflammatory cytokines and chemokines, such as IL-6, IL-8 and MCP-1, either dependently or independently to activate transcriptional factors, such as NF-kB and activator protein 1 (20). Results from the present study demonstrated that transcriptional regulation of the CSE gene was possibly mediated on the NF- $\mathrm{kB}$ binding site on the promoter in HUVECs after treatment with TNFa. After the transfected $293 \mathrm{~T}$ cells were incubated with TNFa $(10 \mathrm{ng} / \mathrm{ml})$ for 1,3 and $6 \mathrm{~h}$, the wild-type promoter activity of the CSE gene significantly increased at $1 \mathrm{~h}$. However, the mutant-type promoter activity of the CSE gene considerably decreased at $1 \mathrm{~h}$. When comparing the action of the wild-type promoter and the mutant-type, it was found that the CSE gene promoter activity significantly decreased with the mutation at 10,30 and $50 \mathrm{ng} / \mathrm{ml}$ for $1 \mathrm{~h}$. CSE expression was upregulated at a low concentration of TNF $\alpha$ over a short time period, whereas it was suppressed with the high concentration of TNF $\alpha$ and a longer treatment time. This suggest that TNF $\alpha$ exerted a concentration- and time-dependent effect on CSE expression. In HUVECs, the high concentration $(50 \mathrm{ng} / \mathrm{ml})$ of TNF $\alpha$ and a longer treatment duration $(6 \mathrm{~h})$ downregulated CSE expression, which may reduce endogenous $\mathrm{H}_{2} \mathrm{~S}$ production and induce the inhibition of vascular smooth muscle relaxation (38) resulting in reduced local blood flow (39). This may lead to the chronic insufficiency of blood supply to local tumor tissue, resulting in the induction of apoptosis (19) and in the prevention of tumor recurrence, this suggests a potential therapeutic target for tumor (40). These results demonstrated that the DNA sequence, GGGACATTCC, on the CSE gene promoter was directly associated with the transcriptional regulation of the CSE gene in mammalian cells treated with TNF $\alpha$. In the present study, the effect of TNF $\alpha$ on the transcription regulation and expression of the CSE gene in HUVECs and 293T cells. However, further studies in animal models are required in future experiments.
In conclusion, results from the present study suggest that the NF- $\mathrm{KB}$ binding site on the CSE promoter is potentially important for $\mathrm{TNF} \alpha$-induced CSE expression. $\mathrm{TNF} \alpha$ can potentially affect CSE gene expression, where vascular endothelial cells can respond to TNF $\alpha$ in the blood by regulating the CSE gene expression. Consequently, the regulatory mechanisms associated with the effects of TNF $\alpha$ on the transcriptional regulation of the CSE gene in HUVECs via the NF- $\mathrm{KB}$ pathway warrant further investigation.

\section{Acknowledgements}

The author thanks Dr Fei Zhou of Hanshan Normal University (Guangdong, China) and Madame Rong-Lan Shi of Hanshan Normal University (Guangdong, China) for their technical assistance.

\section{Funding}

Natural Science Foundation of Guangdong Province (grant no. 2016A030307039) supported this project.

\section{Availability of data and materials}

The datasets used and/or analyzed during the current study are available from the corresponding author on reasonable request.

\section{Authors' contributions}

MW contributed to this study independently; read and approved the final version of the manuscript; and confirmed the authenticity of all the raw data.

\section{Ethics approval and consent to participate}

Not applicable.

\section{Patient consent for publication}

Not applicable.

\section{Competing interests}

The authors declare that they have no competing interests.

\section{References}

1. Wang R: Hydrogen sulfide: The third gasotransmitter in biology and medicine. Antioxid Redox Signal 12: 1061-1064, 2010.

2. Choi KS, Song H, Kim EH, Choi JH, Hong H, Han YM and Hahm KB: Inhibition of hydrogen sulfide-induced angiogenesis and inflammation in vascular endothelial cells: Potential mechanisms of gastric cancer prevention by Korean red ginseng. J Ginseng Res 36: 135-145, 2012.

3. Aboubakr EM, Taye A, El-Moselhy MA and Hassan MK: Protective effect of hydrogen sulfide against cold restraint stress-induced gastric mucosal injury in rats. Arch Pharm Res 36: 1507-1515, 2013.

4. Kan J, Guo W, Huang C, Bao G, Zhu Y and Zhu YZ: S-propargyl-cysteine, a novel water-soluble modulator of endogenous hydrogen sulfide, promotes angiogenesis through activation of signal transducer and activator of transcription 3 . Antioxid Redox Signal 20: 2303-2316, 2014. 
5. Leskova A, Pardue S, Glawe JD, Kevil CG and Shen X: Role of thiosulfate in hydrogen sulfide-dependent redox signaling in endothelial cells. Am J Physiol Heart Circ Physiol 313: H256-H264, 2017.

6. You X, Chen Z, Zhao H, Xu C, Liu W, Sun Q, He P, Gu H and Ni X: Endogenous hydrogen sulfide contributes to uterine quiescence during pregnancy. Reproduction 153: 535-543, 2017.

7. Zhang D, Wang X, Tian X, Zhang L, Yang G, Tao Y, Liang C, Li K, Yu X, Tang X, et al: The increased endogenous sulfur dioxide acts as a compensatory mechanism for the downregulated endogenous hydrogen sulfide pathway in the endothelial cell inflammation. Front Immunol 9: 882, 2018.

8. GarattiniEG, Santos BM,Ferrari DP, CapelCP, Francescato HDC, Coimbra TM, Leite-Panissi CRA, Branco LGS and Nascimento GC: Propargylglycine decreases neuro-immune interaction inducing pain response in temporomandibular joint inflammation model. Nitric Oxide 93: 90-101, 2019.

9. Wijerathne CUB, Madduma Hewage S, Siow YL and O K Kidney ischemia-reperfusion decreases hydrogen sulfide and increases oxidative stress in the heart. Biomolecules 10: 1565, 2020.

10. Pahl HL: Activators and target genes of Rel/NF-kappaB transcription factors. Oncogene 18: 6853-6866, 1999.

11. Baeuerle PA and Baltimore D: NF-kappa B: Ten years after. Cell 87: 13-20, 1996.

12. Wang Y, Zhao X, Jin H, Wei H, Li W, Bu D, Tang X, Ren Y, Tang $\mathrm{C}$ and $\mathrm{Du} \mathrm{J}$ : Role of hydrogen sulfide in the development of atherosclerotic lesions in apolipoprotein E knockout mice. Arterioscler Thromb Vasc Biol 29: 173-179, 2009.

13. Clyde K. and Glaunsinger BA: Chapter 1 - Getting the Message: Direct Manipulation of Host mRNA Accumulation During Gammaherpesvirus Lytic Infection. In: Advances in Virus Research. Maramorosch K, Shatkin AJ and Murphy FA (eds). Vol 78. Academic Press, Burlington, MA, pp1-42, 2010..

14. Perna AF, Sepe I, Lanza D, Capasso R, Zappavigna S, Capasso G Caraglia $M$ and Ingrosso D: Hydrogen sulfide reduces cell adhesion and relevant inflammatory triggering by preventing ADAM17-dependent TNF- $\alpha$ activation. J Cell Biochem 114: 1536-1548, 2013

15. Shirozu K, Tokuda K, Marutani E, Lefer D, Wang R and Ichinose F: Cystathionine $\gamma$-lyase deficiency protects mice from galactosamine/lipopolysaccharide-induced acute liver failure. Antioxid Redox Signal 20: 204-216, 2014

16. Ahmad A, Gero D, Olah G and Szabo C: Effect of endotoxemia in mice genetically deficient in cystathionine- $\gamma$-lyase, cystathionine- $\beta$-synthase or 3 -mercaptopyruvate sulfurtransferase. Int J Mol Med 38: 1683-1692, 2016.

17. Hu HJ, Jiang ZS, Zhou SH and Liu QM: Hydrogen sulfide suppresses angiotensin II-stimulated endothelin-1 generation and subsequent cytotoxicity-induced endoplasmic reticulum stress in endothelial cells via NF-кB. Mol Med Rep 14: 4729-4740, 2016.

18. Wang YH, Huang JT, Chen WL, Wang RH, Kao MC, Pan YR, Chan SH, Tsai KW, Kung HJ, Lin KT and Wang LH: Dysregulation of cystathionine $\gamma$-lyase promotes prostate cancer progression and metastasis. EMBO Rep 20: e45986, 2019.

19. Wang Y, Zhang C, Xu C, Feng L, Li A, Jin X, Guo S, Jiao X, Liu J, Guo Y, et al: H2S mediates apoptosis in response to inflammation through PI3K/Akt/NFkB signaling pathway. Biotechnol Lett 42: 375-387, 2020

20. Zhang H, Park Y, Wu J, Chen XP, Lee S, Yang J, Dellsperger KC and Zhang C: Role of TNF-alpha in vascular dysfunction. Clin Sci (Lond) 116: 219-230, 2009.

21. Wu C, Xu Z and Huang K: Effects of dietary selenium on inflammation and hydrogen sulfide in the gastrointestinal tract in chickens. Biol Trace Elem Res 174: 428-435, 2016.

22. Xu C, Wan Y, Guo T and Chen X: Effect of hydrogen sulfide on the expression of CSE, NF-kB, and IL-8 mRNA in GES-1 cells with Helicobacter pylori infection. Zhong Nan Da Xue Xue Bao Yi Xue Ban 38: 977-983, 2013 (In Chinese).

23. Xu Y, Du HP, Li J, Xu R, Wang YL, You SJ, Liu H, Wang F, Cao YJ, Liu CF and Hu LF: Statins upregulate cystathionine $\gamma$-lyase transcription and $\mathrm{H} 2 \mathrm{~S}$ generation via activating Akt signaling in macrophage. Pharmacol Res 87: 18-25, 2014.
24. Schmittgen TD and Livak KJ: Analyzing real-time PCR data by the comparative C(T) method. Nat Protoc 3: 1101-1108, 2008

25. Wang M, Guo Z and Wang S: The binding site for the transcription factor, NF-kB, on the cystathionine $\gamma$-lyase promoter is critical for LPS-induced cystathionine $\gamma$-lyase expression. Int J Mol Med 34: 639-645, 2014.

26. Zhang H, Zhi L, Moochhala S, Moore PK and Bhatia M: Hydrogen sulfide acts as an inflammatory mediator in cecal ligation and puncture-induced sepsis in mice by upregulating the production of cytokines and chemokines via NF-kappaB. Am J Physiol Lung Cell Mol Physiol 292: L960-L971, 2007.

27. Tokuda K, Kida K, Marutani E, Crimi E, Bougaki M, Khatri A, Kimura $\mathrm{H}$ and Ichinose $\mathrm{F}$ : Inhaled hydrogen sulfide prevents endotoxin-induced systemic inflammation and improves survival by altering sulfide metabolism in mice. Antioxid Redox Signal 17: 11-21, 2012

28. Marko L, Szijártó IA, Filipovic MR, Kaßmann M, Balogh A, Park JK, Przybyl L, N'diaye G, Krämer S, Anders J, et al: Role of cystathionine gamma-lyase in immediate renal impairment and inflammatory response in acute ischemic kidney injury. Sci Rep 6: 27517, 2016.

29. Ivanciuc T, Sbrana E, Ansar M, Bazhanov N, Szabo C, Casola A and Garofalo RP: Hydrogen sulfide is an antiviral and antiinflammatory endogenous gasotransmitter in the airways. Role in respiratory syncytial virus infection. Am J Respir Cell Mol Biol 55: 684-696, 2016.

30. Wallace JL: Hydrogen sulfide-releasing anti-inflammatory drugs. Trends Pharmacol Sci 28: 501-505, 2007.

31. Ganster F, Burban M, de la Bourdonnaye M, Fizanne L, Douay O, Loufrani L, Mercat A, Calès P, Radermacher P, Henrion D, et al: Effects of hydrogen sulfide on hemodynamics, inflammatory response and oxidative stress during resuscitated hemorrhagic shock in rats. Crit Care 14: R165, 2010.

32. Guo W, Cheng ZY and Zhu YZ: Hydrogen sulfide and translational medicine. Acta Pharmacol Sin 34: 1284-1291, 2013

33. Xu ZS, Wang XY, Xiao DM, Hu LF, Lu M, Wu ZY and Bian JS: Hydrogen sulfide protects MC3T3-E1 osteoblastic cells against $\mathrm{H} 2 \mathrm{O} 2$-induced oxidative damage-implications for the treatment of osteoporosis. Free Radic Biol Med 50: 1314-1323, 2011

34. Huang CW, Feng W, Peh MT, Peh K, Dymock BW and Moore PK: A novel slow-releasing hydrogen sulfide donor, FW1256, exerts anti-inflammatory effects in mouse macrophages and in vivo. Pharmacol Res 113: 533-546, 2016.

35. Liu Y, Liao R, Qiang Z and Zhang C: Pro-inflammatory cytokine-driven PI3K/Akt/Sp1 signalling and $\mathrm{H} 2 \mathrm{~S}$ production facilitates the pathogenesis of severe acute pancreatitis. Biosci Rep 37: BSR20160483, 2017.

36. Zhao H, Lu S, Chai J, Zhang Y, Ma X, Chen J, Guan Q, Wan $\mathrm{M}$ and Liu Y: Hydrogen sulfide improves diabetic wound healing in ob/ob mice via attenuating inflammation. J Diabetes Complications 31: 1363-1369, 2017.

37. Castelblanco M, Lugrin J, Ehirchiou D, Nasi S, Ishii I, So A, Martinon F and Busso N: Hydrogen sulfide inhibits NLRP3 inflammasome activation and reduces cytokine production both in vitro and in a mouse model of inflammation. J Biol Chem 293: 2546-2557, 2018.

38. Kimura H: Production and physiological effects of hydrogen sulfide. Antioxid Redox Signal 20: 783-793, 2014.

39. Wallace JL and Wang R: Hydrogen sulfide-based therapeutics: Exploiting a unique but ubiquitous gasotransmitter. Nat Rev Drug Discov 14: 329-345, 2015.

40. Sogutdelen E, Pacoli K, Juriasingani S, Akbari M, Gabril M and Sener A: Patterns of expression of H2S-producing enzyme in human renal cell carcinoma specimens: Potential avenue for future therapeutics. In Vivo 34: 2775-2781, 2020. 